\title{
A novel and effective technology for mitigating nitrous oxide emissions from land-applied manures
}

\author{
Jaye Hill ${ }^{\mathrm{A}}$, Matthew Redding ${ }^{\mathrm{A}}$ and Chris Pratt $^{\mathrm{A}, \mathrm{B}}$ \\ ADepartment of Agriculture and Fisheries, 203 Tor Street, Toowoomba, Qld 4350, Australia. \\ ${ }^{B}$ Corresponding author. Email: christopher.pratt@daf.qld.gov.au
}

\begin{abstract}
Land-applied manures produce nitrous oxide $\left(\mathrm{N}_{2} \mathrm{O}\right)$, a greenhouse gas (GHG). Land application can also result in ammonia $\left(\mathrm{NH}_{3}\right)$ volatilisation, leading to indirect $\mathrm{N}_{2} \mathrm{O}$ emissions. Here, we summarise a glasshouse investigation into the potential for vermiculite, a clay with a high cation exchange capacity, to decrease $\mathrm{N}_{2} \mathrm{O}$ emissions from livestock manures (beef, pig, broiler, layer), as well as urea, applied to soils. Our hypothesis is that clays adsorb ammonium, thereby suppressing $\mathrm{NH}_{3}$ volatilisation and slowing $\mathrm{N}_{2} \mathrm{O}$ emission processes. We previously demonstrated the ability of clays to decrease emissions at the laboratory scale. In this glasshouse work, manure and urea application rates varied between 50 and $150 \mathrm{~kg}$ nitrogen $(\mathrm{N}) / \mathrm{ha}$. Clay : manure ratios ranged from $1: 10$ to $1: 1$ (dry weight basis). In the 1-year trial, the abovementioned $\mathrm{N}$ sources were incorporated with vermiculite in $1 \mathrm{~L}$ pots containing Sodosol and Ferrosol growing a model pasture (Pennisetum clandestinum or kikuyu grass). Gas emissions were measured periodically by placing the pots in gastight bags connected to real-time continuous gas analysers. The vermiculite achieved significant $(P \leq 0.05)$ and substantial decreases in $\mathrm{N}_{2} \mathrm{O}$ emissions across all $\mathrm{N}$ sources (70\% on average). We are currently testing the technology at the field scale; which is showing promising emission decreases $(\sim 50 \%)$ as well as increases $(\sim 20 \%)$ in dry matter yields. This technology clearly has merit as an effective GHG mitigation strategy, with potential associated agronomic benefits, although it needs to be verified by a cost-benefit analysis.
\end{abstract}

Additional keywords: agriculture, greenhouse gas mitigation, manure management, nitrogen, vermiculite.

Received 31 August 2015, accepted 6 November 2015, published online 9 February 2016

\section{Introduction}

Agriculture is a major emitter of nitrous oxide $\left(\mathrm{N}_{2} \mathrm{O}\right)$, which is a potent greenhouse gas (GHG) and ozone-degrader (Ravishankara et al. 2009). On farms, manure and fertiliser application to soil is the predominant $\mathrm{N}_{2} \mathrm{O}$ emission source (Bouwman 1996; Mosier et al. 1998).

There is strong demand for technology-based solutions to mitigate these agricultural $\mathrm{N}_{2} \mathrm{O}$ emissions (Snyder et al. 2014), given the recent mounting pressure to include food-derived GHG emissions into similar regulation frameworks that exist to manage energy emissions (McMichael et al. 2007; Koneswaran and Nierenberg 2008; Cederberg et al. 2013). Several studies have focussed on inhibitor-based technologies to supress $\mathrm{N}_{2} \mathrm{O}$ and ammonia $\left(\mathrm{NH}_{3}\right.$, which leads to indirect $\mathrm{N}_{2} \mathrm{O}$ formation) emissions from fertilised landscapes. Inhibitors tested include urease inhibitors, such as N-(n-butyl) thiophosphoric triamide, and nitrification inhibitors, including dicyandiamide (DCD). These compounds have achieved substantial decreases (>50\%) in both $\mathrm{N}_{2} \mathrm{O}$ emission (McTaggart et al. 1997) and $\mathrm{NH}_{3}$ (Saggar et al. 2013) volatilisation. However, concerns have been raised over the persistent effects of these complex chemicals in agronomic systems. For example, Krogmeier et al. (1989) reported that $\mathrm{N}$-(n-butyl) thiophosphoric triamide can result in leaf-tip necrosis in plants. Moreover, with continually improving detection limits, several recent studies have detected DCD in dairy cattle milk produced for human consumption (Danaher and Jordan 2013; Inoue et al. 2014; Lin et al. 2015). The modes of transport of DCD into milk are not yet fully established, although a recent study by Pal et al. (2015) demonstrated that foliar and root absorption could represent a significant source of contamination on pastures.

Instead of using chemical inhibitors, with their associated persistence and contamination risks, the use of naturally occurring minerals with high cation exchange capacity (CEC) could offer a lower-risk approach towards mitigating land-applied fertiliser and manure emissions. The theory underpinning this concept was pioneered by Zaman et al. (2007) who showed that high-CEC zeolites can be used to slow the kinetics of $\mathrm{NH}_{3}$ volatilisation and nitrogen $(\mathrm{N})$ mineralisation, thereby decreasing the overall rate of $\mathrm{N}_{2} \mathrm{O}$ production. These authors documented a 30-40\% decrease in $\mathrm{N}_{2} \mathrm{O}$ emissions from urea and dairy cattle urine applied to volcanic and organic wetland soils amended with zeolite.

Clay minerals of the phyllosilicate class also possess high CECs. Clays are far more abundant and ubiquitously distributed than are zeolites and their plate structure might help avoid clogging problems that can arise in the 3-D porous structure of zeolites (Mumpton and Fishman 1977). The ability of clays 
to decrease $\mathrm{N}_{2} \mathrm{O}$ emissions from land-applied fertilisers is, therefore, novel and merits testing.

In earlier laboratory-scale research, we observed $\mathrm{N}_{2} \mathrm{O}$ and $\mathrm{NH}_{3}$ emission decreases of up to $90 \%$ from soils amended with pig litter and high-CEC clays (vermiculite and bentonite; Pratt et al. 2015b). We also observed similar results for other livestock manures at a laboratory scale (Pratt et al. 2016). Here, we build on the outcomes from our early laboratory-scale research by investigating the potential for a high-CEC clay, vermiculite, to decrease $\mathrm{NH}_{3}$ and $\mathrm{N}_{2} \mathrm{O}$ emissions from manure-amended soils at the glasshouse scale. This glasshouse trial involves several key aspects that were not assessed in our preliminary laboratory research, including (1) testing across two different soil types, (2) evaluation of emission responses across different $\mathrm{N}$ addition rates, (3) the use of conventional chemical fertilisers, as well as manures and (4) the incorporation of a model plant in the amendments. We envisage that the outcomes will help deliver a workable technology to mitigate on-farm emissions and help farmers cope with emerging challenges of food production.

\section{Materials and methods}

\section{Manure collection and preparation}

We targeted manures from a range of Australia intensive livestock industries, i.e. beef feedlot pen surface, fresh piggery litter, broiler poultry litter and fresh poultry layer manure. Specific details of farms accessed and manure collection are given in earlier published work (Pratt et al. 2015a).

\section{Soil and vermiculite collection and preparation}

The vermiculite $\left.\left(\mathrm{Mg}^{+2}, \mathrm{Fe}^{+2}, \mathrm{Fe}^{+3}\right)_{3}\left[(\mathrm{AlSi})_{4} \mathrm{O}_{10}\right] \cdot(\mathrm{OH})_{2} \bullet 4 \mathrm{H}_{2} \mathrm{O}\right)$ was a commercially available product (Brunnings, Melbourne, Vic., Australia), which we ground to a coarse powder $(<1 \mathrm{~mm})$ with a RETSCH SK100 grinder (Germany).

Approximately $100 \mathrm{~kg}$ of a sandy Sodosol was collected from an undisturbed pasture in Warwick, $\sim 170 \mathrm{~km}$ south-west of Brisbane (Australia). The site has a history of livestock grazing, but has been undisturbed for the past decade. Approximately $100 \mathrm{~kg}$ of a Ferrosol was collected from an undisturbed pasture in Toowoomba, $120 \mathrm{~km}$ west of Brisbane. The site has no history of agricultural activity.

Both soils were collected to a depth of $\sim 10 \mathrm{~cm}$ by using a frontloader excavator. Coarse debris was removed from the soils with a purpose-built, suspended sieve ( $2 \mathrm{~mm}$ aperture, $1 \mathrm{~m}$ diameter) with a mechanical agitator. The soil moisture contents were measured by oven-drying and then brought up to $20 \%$ and $42 \%$ gravimetric water content (dry weight basis) for the Sodosol and Ferrosol, respectively, which from our earlier work on these soils had been shown to be favourable for GHG emissions (data not shown).

\section{Glasshouse pot set-up}

In total, $240 \times 1 \mathrm{~L}$ pots were established in a temperaturecontrolled $\left(25^{\circ} \mathrm{C}\right)$ glasshouse. A total of 120 pots each received $1500 \mathrm{~g}$ of sieved field-moist Sodosol (oven dry equivalent: $<2 \mathrm{~mm}$ ). The remaining 120 pots received $900 \mathrm{~g}$ (oven dry equivalent weight) of field-moist Ferrosol. Approximately $10 \mathrm{~g}$ of kikuyu grass (Pennisetum clandestinum) seeds were sprinkled onto the surface of each soil and pressed gently into the soil to promote germination. The soils were watered and the seeds were left to germinate for several weeks until the pots were well established with kikuyu seedlings ( $\approx 30$ individual plants per pot). Nutrient additions (expect $\mathrm{N}$ ) were made to achieve optimum plant.

\section{Manure and vermiculite incubation}

Prior to incorporating the manures and vermiculite into the pasture-covered Sodosol and Ferrosol pots, we incubated them at saturation for 5 days, according to the procedure outlined by Redding (2011), so as to expedite contact between the vermiculite sorption sites and the ammonium $\left(\mathrm{NH}_{4}{ }^{+}\right)$in the manures. The incubations were performed in sealed vessels fitted with an outlet gas line directed into a $40 \mathrm{~mL}$ water trap to prevent vessel explosion resulting from carbon dioxide pressure build-up and to capture any dissolved $\mathrm{NH}_{4}^{+}$and nitrous oxide $\left(\mathrm{N}_{2} \mathrm{O}\right)$. Following incubation, water from each trap was poured back into each treatment and both the water content used to saturate the incubations and the water from the traps were factored into final soil moisture calculations. We monitored ammonia $\left(\mathrm{NH}_{3}\right)$ and $\mathrm{N}_{2} \mathrm{O}$ emissions from the incubation water traps by using the continuous gas analysers. Emissions of both gases were at background levels $(20 \mu \mathrm{g} / \mathrm{L}$ for $\mathrm{NH}_{3}$ and $330 \mu \mathrm{g} / \mathrm{L}$ for $\mathrm{N}_{2} \mathrm{O}$ ), which indicated negligible $\mathrm{N}$ gaseous loss from the manures during incubation (full details of the gas analysis system are presented in the following section).

Five vermiculite rates were mixed with the manures $(0,0.7$, 1.5, 3 and 7.4 meq CEC/meq $\mathrm{NH}_{4}{ }^{+}-\mathrm{N}$ in the manure). We also incubated vermiculite with an inorganic fertiliser source, urea (refer to Table 1 for amounts). The selected vermiculite contents corresponded to very low clay: soil volume ratios ( $\max 5 \%$ ), thereby minimising the physical effects of clay on emission responses. The vermiculite additions corresponded to an application equivalent of $0.27-7 \mathrm{t} / \mathrm{ha}$ across the treatments. The manure and urea quantities were chosen to represent a $\mathrm{N}$ loading rate of $150 \mathrm{~kg} \mathrm{~N} / \mathrm{ha}$ and $50 \mathrm{~kg} \mathrm{~N} / \mathrm{ha}$ in our pots, which covers a range of typical $\mathrm{N}$ addition rates to agricultural soils (Gregorich et al. 2014; Shcherbak et al. 2014). The combinations of manures and vermiculite incubations are shown in Table 1.

Each of the incubation combinations shown in Table 1 was applied in duplicate to the Sodosol and Ferrosol soils (total=200).

Table 1. Quantities of manures, urea and vermiculite used

\begin{tabular}{lccccc}
\hline $\begin{array}{l}\text { Nitrogen (N) source } \\
\text { (dry weights) }\end{array}$ & \multicolumn{5}{c}{ Vermiculite addition (g) } \\
& Level 0 & Level 1 & Level 2 & Level 3 & Level 4 \\
Beef: $5.45 \mathrm{~g}$ & 0 & 0.8 & 1.6 & 3.2 & 8.0 \\
Pig: $11.9 \mathrm{~g}$ & 0 & 0.8 & 1.6 & 3.2 & 8.0 \\
Poultry: $4.15 \mathrm{~g}$ & 0 & 0.8 & 1.6 & 3.2 & 8.0 \\
Egg: $2.72 \mathrm{~g}$ & 0 & 0.8 & 1.6 & 3.2 & 8.0 \\
Urea: $0.36 \mathrm{~g}$ & 0 & 0.8 & 1.6 & 3.2 & 8.0 \\
& & $50 \mathrm{~kg} \mathrm{~N} / \mathrm{ha}$ & & & \\
Beef: $1.82 \mathrm{~g}$ & 0 & 0.27 & 0.5 & 1.0 & 2.7 \\
Pig: $3.98 \mathrm{~g}$ & 0 & 0.27 & 0.5 & 1.0 & 2.7 \\
Poultry: $1.38 \mathrm{~g}$ & 0 & 0.27 & 0.5 & 1.0 & 2.7 \\
Egg: $0.91 \mathrm{~g}$ & 0 & 0.27 & 0.5 & 1.0 & 2.7 \\
Urea: $0.12 \mathrm{~g}$ & 0 & 0.27 & 0.5 & 1.0 & 2.7 \\
\hline
\end{tabular}


The remaining 20 Sodosol pots and 20 Ferrosol pots had no manure additions, providing an experimental control.

A layer of the manure and vermiculite treatment was placed on the soil surface. So as to decrease volatilisation losses, additional soil was placed in a layer over the treatment material, namely, a further $170 \mathrm{~g}$ of soil for the Sodosol pots and $94 \mathrm{~g}$ for the Ferrosol pots. This 'sandwiching' of manure in the top few centimetres of the soil profile simulated subsurface manure incorporation techniques commonly applied to agricultural landscapes (Natvig et al. 2002; Dell et al. 2012) The 40 remaining baseline control pots (20 containing Sodosol and 20 containing Ferrosol) were topped up with the same covering amount of soil as for the other pots. The soils in all Sodosol and Ferrosol pots were brought up to $20 \%$ and $42 \%$ gravimetric water content (dry weight basis), respectively.

The bulk densities of each treatment are shown in Table 2. The pots were arranged in a row-column design throughout the glasshouse. The two different soils formed two randomised row-column blocks in the glasshouse.

\section{Gas measurements}

The gas analysis system used in our study was adapted from Redding et al. (2016). It comprised an automated 32-channel gas manifold, with inlets connected to collapsible bags in which the pots were placed during gas analysis. Due to limited positions (32) on the manifold, we targeted pots with vermiculite addition rates 0,2 and 4 (refer to Table 1 for details). A visual snapshot of the gas analysis set-up is shown in Fig. 1.

We analysed emissions from one soil type at a time. The pots were taken from their glasshouse places and placed into the bags for 2-day continuous measurement periods. After 2 days, the pots were removed from their bags and returned to their glasshouse positions, while the pots comprising the other soil type were analysed. The duplicate pots were placed together in each bag. One empty bag was used as a blank to obtain baseline concentrations. Two $4 \mathrm{~mm}$ push-fit ports were fitted into the bags. One was open to the atmosphere, while the other was connected to a solenoid valve on a 32-channel switching gas manifold. These valves linked into a central gas line, which was connected to a mass flow controller coupled with a vacuum pump. When bags were not being sampled for their gas concentrations, the valves were sealed. During sampling, ambient air from the glasshouse was swept through a bag and directed to a Los Gatos (CA, USA) isotopic $\mathrm{N}_{2} \mathrm{O}$ analyser $\left(\mathrm{N}_{2} \mathrm{O}\right)$ and a cavity ring-down spectroscopy $\mathrm{NH}_{3}$ analyser (Picarro, CA, USA). Both analysers take continuous measurements, with data logged every $20 \mathrm{~s}$ for the Los Gatos instruments and every second for the Picarro analyser.

Gas fluxes were calculated by integrating the average concentrations measured in the bags with the gas sweep flow rate $(3.5 \mathrm{~L} / \mathrm{min})$ and the sweep time $(10 \mathrm{~min})$. Volumetric fluxes were converted to mass fluxes by applying the ideal gas law to concentration data. We concluded the gas analyses after 2 months, when emissions from the pots had largely ceased. We were able to collect 22 gas measurement readings for each treatment. We achieved $98 \%$ recovery of an $\mathrm{N}_{2} \mathrm{O}$ standard injected through the gas measurement system, indicating that the method was accurate.

\section{Pot maintenance and plant harvesting}

The pots were watered (deionised water) three times weekly to maintain the soils at their starting moisture contents (determined by weighing). The shoots were harvested from all pots approximately monthly and the dry $\left(65^{\circ} \mathrm{C}\right)$ weights from each cut recorded. As only one nutrient application was made (equivalent to 50 and $150 \mathrm{~kg} / \mathrm{ha}$ ) during the 10 month growing period, harvests continued as pots became $\mathrm{N}$ deficient. Ten cuts were completed during the trial.

\section{Physicochemical analyses}

Moisture contents were determined by oven-drying the manure and soil overnight at $60^{\circ} \mathrm{C}$ and $105^{\circ} \mathrm{C}$, respectively, and recording

Table 2. Bulk densities $\left(\mathrm{g} / \mathrm{cm}^{3}\right)$ of the various treatments

$\mathrm{N}$, nitrogen

\begin{tabular}{|c|c|c|c|c|c|c|c|c|c|c|}
\hline \multirow[t]{2}{*}{ Treatment } & \multicolumn{2}{|c|}{$\begin{array}{l}\text { Level } 0 \text { vermiculite } \\
\text { addition }\end{array}$} & \multicolumn{2}{|c|}{$\begin{array}{l}\text { Level } 1 \text { vermiculite } \\
\text { addition }\end{array}$} & \multicolumn{2}{|c|}{$\begin{array}{c}\text { Level } 2 \text { vermiculite } \\
\text { addition }\end{array}$} & \multicolumn{2}{|c|}{$\begin{array}{l}\text { Level } 3 \text { vermiculite } \\
\text { addition }\end{array}$} & \multicolumn{2}{|c|}{$\begin{array}{c}\text { Level } 4 \text { vermiculite } \\
\text { addition }\end{array}$} \\
\hline & Sodosol & Ferrosol & Sodosol & Ferrosol & Sodosol & Ferrosol & Sodosol & Ferrosol & Sodosol & Ferrosol \\
\hline \multicolumn{11}{|c|}{$150 \mathrm{~kg} \mathrm{~N} / \mathrm{ha}$} \\
\hline Soil only & 1.67 & 1.0 & n.a. & n.a. & n.a. & n.a. & n.a. & n.a. & n.a. & n.a. \\
\hline Beef manure & 1.67 & 1.0 & 1.66 & 1.0 & 1.66 & 1.0 & 1.66 & 1.0 & 1.65 & 0.99 \\
\hline Pig litter & 1.63 & 0.98 & 1.63 & 0.98 & 1.63 & 0.98 & 1.63 & 0.98 & 1.62 & 0.98 \\
\hline Poultry litter & 1.66 & 1.0 & 1.66 & 1.0 & 1.66 & 1.0 & 1.66 & 1.0 & 1.64 & 1.0 \\
\hline Egg manure & 1.67 & 1.0 & 1.67 & 1.0 & 1.66 & 1.0 & 1.66 & 1.0 & 1.66 & 1.0 \\
\hline Urea & 1.67 & 1.0 & 1.67 & 1.0 & 1.67 & 1.0 & 1.66 & 1.0 & 1.65 & 1.0 \\
\hline \multicolumn{11}{|c|}{$50 \mathrm{~kg} \mathrm{~N} / \mathrm{ha}$} \\
\hline Soil only & \multicolumn{10}{|c|}{ As for $150 \mathrm{~kg} \mathrm{~N} / \mathrm{ha}$} \\
\hline Beef manure & 1.67 & 1.0 & 1.67 & 1.0 & 1.67 & 1.0 & 1.67 & 1.0 & 1.67 & 1.0 \\
\hline Pig litter & 1.67 & 1.0 & 1.67 & 1.0 & 1.67 & 1.0 & 1.67 & 1.0 & 1.67 & 1.0 \\
\hline Poultry litter & 1.67 & 1.0 & 1.67 & 1.0 & 1.67 & 1.0 & 1.67 & 1.0 & 1.67 & 1.0 \\
\hline Egg manure & 1.67 & 1.0 & 1.67 & 1.0 & 1.67 & 1.0 & 1.67 & 1.0 & 1.67 & 1.0 \\
\hline Urea & 1.67 & 1.0 & 1.67 & 1.0 & 1.67 & 1.0 & 1.67 & 1.0 & 1.67 & 1.0 \\
\hline
\end{tabular}




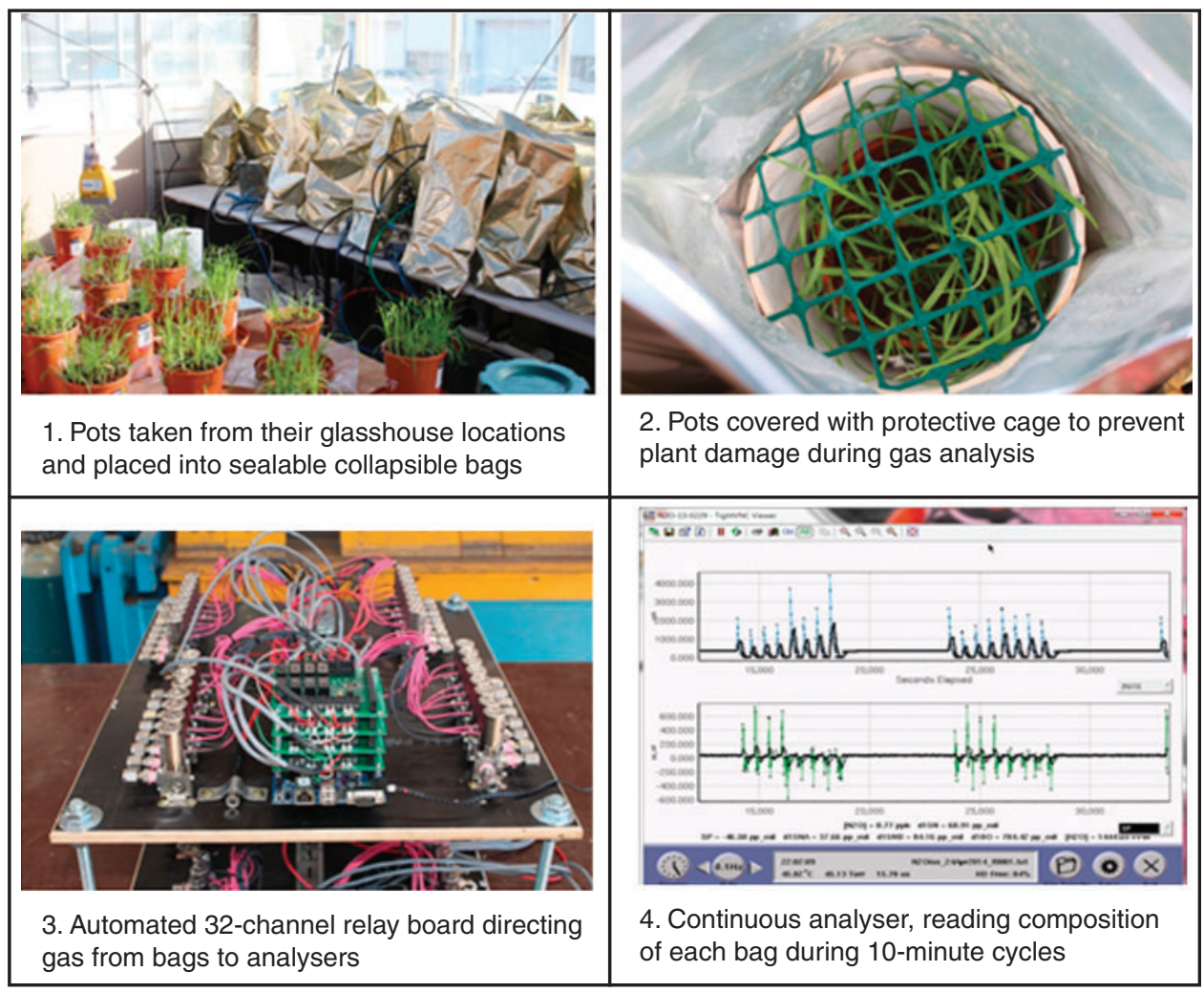

Fig. 1. Set-up of the pot gas analysis system.

weight loss. The $\mathrm{pH}$ for the manures and the soil was measured using a $\mathrm{pH}$ meter, following a solid: water (1:5) extraction. Total (Dumas) N was analysed using a Leco analyser (NSW, Australia) following the Dumas dry combustion principle where samples are combusted at $1050^{\circ} \mathrm{C}$. This method has been well described in previous work (Buckee 1994).

Organic $\mathrm{C}$ was quantified colourimetrically after digestion with $\mathrm{H}_{2} \mathrm{SO}_{4}$ and $\mathrm{K}_{2} \mathrm{Cr}_{2} \mathrm{O}_{7}$ (El-Mashad and Zhang 2010). For the soil, $\mathrm{NH}_{4}{ }^{+}-\mathrm{N}$ was analysed following extraction with $2 \mathrm{M} \mathrm{KCl}$ (1:10 manure: water ratio) and measured colourimetrically using atomic adsorption spectrophotometry. Nitrate+nitrite-N was determined via the same procedure but with addition of Devarda's alloy to determine total mineral-N, and nitrate+nitrite$\mathrm{N}$ calculated by subtraction of $\mathrm{NH}_{4}{ }^{+}-\mathrm{N}$. For the manures, tannin contamination affected the atomic adsorption spectrophotometry method, so these extracts were analysed for their $\mathrm{NH}_{4}{ }^{+}-\mathrm{N}$ and $\mathrm{NO}_{3}{ }^{-}+\mathrm{NO}_{2}{ }^{-}-\mathrm{N}$ concentrations by titration, using $0.01 \mathrm{M} \mathrm{HCl}$ following steam distillation using $\mathrm{MgO}$.

The particle-size distribution of the Sodosol was measured using a gravimetric hydrometer. The $\mathrm{CEC}$ of the vermiculite and bentonite was measured using the unbuffered $\mathrm{NH}_{4} \mathrm{Cl}$ extraction method by Sumner and Miller (1996). The key parameters are shown in Table 3. All manure, soil and clay samples were analysed in triplicate.

\section{Statistical analyses}

ANOVA was performed on log-normalised (due to skewness) cumulative $\mathrm{N}_{2} \mathrm{O}$ emissions from each measured pot (vermiculite level additions 0,2 and 4$)$ to determine significance $(P \leq 0.05)$ for differences in emissions among vermiculite addition levels. ANOVA was also performed on the total dry matter yields, as well as $\mathrm{N}$ uptake, from each pot (across all vermiculite addition levels). Kendall's correlation coefficient was determined for dry matter yields and vermiculite addition for the final three cuts. Statistics were performed using Genstat (2013).

\section{Results and discussion}

\section{Gas emissions}

Measured ammonia $\left(\mathrm{NH}_{3}\right)$ emissions from the pots that underwent gas analysis were negligible $(<40 \mu \mathrm{g} / \mathrm{L}$ above background concentrations). The low $\mathrm{NH}_{3}$ emissions were probably due to the topdressing of the treatments beneath $5 \mathrm{~cm}$ of soil. This incorporation at depth was performed to avoid nutrient burning of the vulnerable pasture seedlings.

Cumulative $\mathrm{N}_{2} \mathrm{O}$ emissions from the pots are shown in Figs S1-S10, available as Supplementary Material for this paper. Emission fluxes from untreated manure and urea applications to the soils were lower than the Intergovernmental Panel on Climate Change (IPCC) emission factors for landapplied manures (0.016). The lower fluxes reported in our work were expected, given that our measurement set-up did not permit continuous capture of emissions, with the pots having to be regularly removed from the bags for plant survival and adequate gas-measurement coverage for the experiment. Given that emissions from the pots were analysed for $\sim 10 \%$ of the emission-measurement period, then broad 
Table 3. Physicochemical composition of manures, urea and vermiculite used

Values are means, with standard deviations in parentheses. $\mathrm{C}_{\text {org }}$, organic carbon; $\mathrm{CEC}$, cation exchange capacity; $\mathrm{N}$, nitrogen; $\mathrm{NH}_{4}$, ammonium; $\mathrm{NO}_{3}$, nitrate

\begin{tabular}{|c|c|c|c|c|c|c|c|}
\hline \multirow[t]{2}{*}{ Parameter } & \multicolumn{4}{|c|}{ Manure } & \multirow{2}{*}{$\begin{array}{c}\text { Clay } \\
\text { Vermiculite }\end{array}$} & \multicolumn{2}{|c|}{ Soil } \\
\hline & Beef feedlot & Piggery deep litter & Poultry litter & Layer manure & & Sodosol & Ferrosol \\
\hline Moisture $\%$ by wet weight & $88(13)$ & $76(0.9)$ & $23(0.5)$ & $130(3.4)$ & - & $0.67(0.29)$ & $5.0(0.27)$ \\
\hline $\mathrm{pH}$ & $7.0(0.04)$ & $8.7(0.04)$ & $8.0(0.04)$ & $6.5(0.08)$ & - & $6.3(0)$ & $6.4(0)$ \\
\hline $\mathrm{C}_{\text {org }}(\%)$ & $37(4.8)$ & $45(1.6)$ & $39(1.1)$ & $33(1.1)$ & $<0.005$ & $0.48(0.05)$ & $3.41(0.1)$ \\
\hline Dumas N (\%) & $3.1(0.5)$ & $1.4(0.05)$ & $4.1(0.4)$ & $6.2(0.4)$ & $<0.005$ & $0.06(0)$ & $0.29(0.01)$ \\
\hline $\mathrm{NH}_{4}-\mathrm{N}(\mathrm{mg} / \mathrm{kg})$ & $1812(82)$ & $3531(22)$ & $4660(147)$ & 7069 (222) & - & $1.34(0.16)$ & $11.8(0.89)$ \\
\hline $\mathrm{NO}_{3}-\mathrm{N}(\mathrm{mg} / \mathrm{kg})$ & $363(202)$ & $577(24)$ & $296(20)$ & $219(34)$ & - & $2.15(0.16)$ & $3.50(0.38)$ \\
\hline Coarse sand (\%) & - & - & - & - & - & $56(1.0)$ & $6.7(0.6)$ \\
\hline Fine sand $(\%)$ & - & - & - & - & - & $37(0.58)$ & $18(0)$ \\
\hline Silt (\%) & - & - & - & - & - & $4.3(0.58)$ & $22(1.5)$ \\
\hline Clay $(\%)$ & - & - & - & - & - & $4.7(0.58)$ & $53(1)$ \\
\hline $\mathrm{CEC}(\mathrm{cmol} / \mathrm{kg})$ & - & - & - & - & $105(1.5)$ & $1.08(0.34)$ & $11.5(1.9)$ \\
\hline
\end{tabular}

emission estimates of $0.002-0.025$ can be extrapolated from the untreated soil manure and urea applications, which is within the IPCC range.

In some of the treatments, particularly at the low $\mathrm{N}$ application rates where the added $\mathrm{N}$ contributed only $2-6 \%$ of existing soil $\mathrm{N}$ content, $\mathrm{N}_{2} \mathrm{O}$ emissions from the soil alone exceeded emissions from the soils amended with manures. It is likely that this was related to differences in physical properties between soil-only treatments and those containing manure and vermiculite. Indeed, gas exchange and physical parameters have been reported to strongly influence $\mathrm{N}_{2} \mathrm{O}$ emissions (Beare et al. 2009; Gregorich et al. 2014). High $\mathrm{N}_{2} \mathrm{O}$ emissions from the soil alone are not surprising, given the presence of an existing $\mathrm{N}$ reservoir, favourable soil moisture levels to accommodate nitrification and denitrification processes, and the presence of nitrifying (e. g. Thaumarchaeota, Nitrospiraceae, Nitrospira) and denitrifying (e.g. Streptomyces, Alicyclobacillus, Bacillus) bacteria, as well as denitrifying fungi (e.g. Fusarium, Trichosporon) in the soils, as confirmed by parallel research.

Nitrous oxide emissions steadily decreased over the 2-month gas emission measurement period, which accords well with emission trends for land-applied manures reported in the literature (Lessard et al. 1996; Chadwick et al. 2000; Sherlock et al. 2002; Ginting et al. 2003; Amon et al. 2006; Rochette et al. 2008).

Emissions from the Ferrosol amendments were lower than those from the Sodosol amendments. This was perhaps due to the higher CEC of the Ferrosol (Table 3), which might have facilitated greater $\mathrm{NH}_{4}{ }^{+}-\mathrm{N}$ adsorption and subsequent suppression of $\mathrm{N}$ mineralisation.

Across all treatments, there was a consistent decrease in emissions with increasing vermiculite addition level (Fig. 2). Moreover, there was a significant $(P \leq 0.05)$ difference in emission flux between the treatments containing no vermiculite and those containing the highest vermiculite addition. The $70 \%$ decrease in $\mathrm{N}_{2} \mathrm{O}$ emissions brought about by the higher rate of vermiculite addition was considerably higher than the $40 \%$ decrease in $\mathrm{N}_{2} \mathrm{O}$ emissions from soils amended with zeolite, observed by Zaman et al. (2007). This difference might have been attributable to the higher CEC of vermiculite (105 $\mathrm{cmol} / \mathrm{kg})$ used in our study than that of the zeolite $(80 \mathrm{cmol} / \mathrm{kg})$

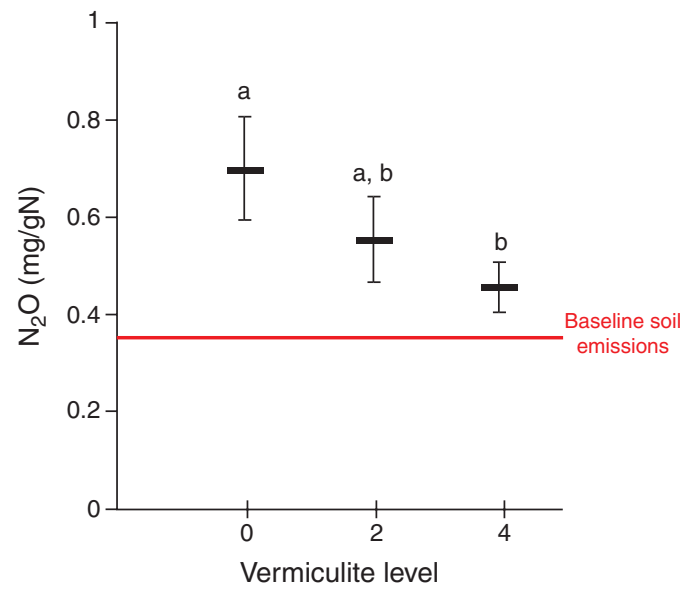

Fig. 2. Geometric means of $\mathrm{N}_{2} \mathrm{O}$ fluxes across all amendments, with standard errors. Common letters indicate that the means are not significantly different (at $P=0.05$ ). Refer to Table 1 for vermiculite addition levels.

used by Zaman et al. (2007). In any case, the approach of using high-CEC materials to decrease N-based GHG emissions from fertilised soils clearly has strong potential. Subsequent tests at a field scale, which will be outlined in detail in a paper to follow, also saw a significant effect of vermiculite on $\mathrm{N}_{2} \mathrm{O}$ emissions on Ferrosol. Gas emissions were measured using a large vented chamber across 96 plots. Overall, the clays have achieved a significant $(P<0.05)$ and substantial decreases in $\mathrm{N}_{2} \mathrm{O}$ emissions across all trials ( $>50 \%$ on average).

\section{Agronomic data}

A technology that decreases GHG emissions at the expense of productivity will not be viable. Therefore, it was important to evaluate the effect of vermiculite on the growth of the kikuyu model plant. We assessed agronomic performance by measuring dry matter yields and nutrient $(\mathrm{N})$ uptake by the shoots in the pots. The cumulative dry matter yields (DMY) from the harvested kikuyu shoots over the 10 months are shown in Fig. 3.

There were no significant $(P>0.05)$ differences in DMY with an increasing level of vermiculite addition for the Ferrosol. For the Sodosol, there were some significant $(P \leq 0.05)$ differences in 


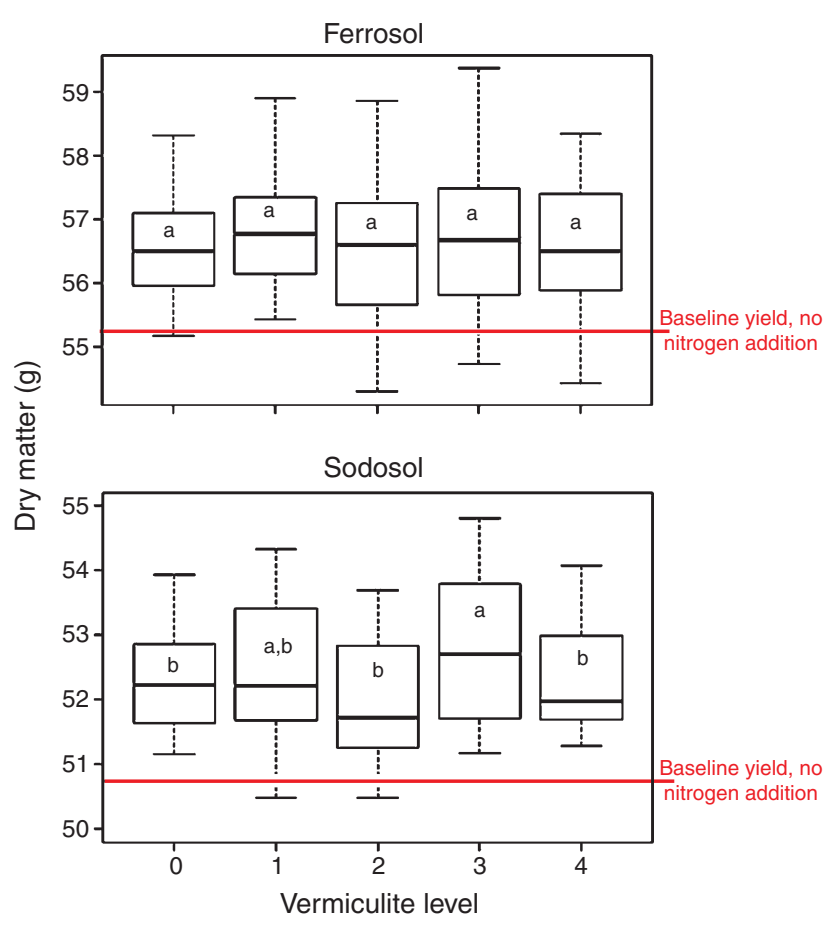

Fig. 3. Box and whisker plots for dry matter yields from harvested kikuyu shoots. Data are cumulative across the entire trial. Common letters indicate that values are not significantly different $(P=0.05)$. Refer to Table 1 for vermiculite addition levels.

yield across each vermiculite level, with greater yields harvested from the pots with the 3rd vermiculite addition level than with the other levels (Fig. 3). However, there were no obvious trends relating DMY with vermiculite addition level. We also observed no significant $(P>0.05)$ effect of vermiculite addition on $\mathrm{N}$ uptake by the model kikuyu plant. This was true when combining the two soils for statistical analysis and when assessing them individually (Fig. 4).

The agronomic results from our glasshouse trial are encouraging as they suggest that the observed significant $(P \leq 0.05)$ decreases in $\mathrm{N}_{2} \mathrm{O}$ emissions caused by the vermiculite did not compromise dry matter production or nutrient uptake, which is important from a productivity perspective. There were even some indications that the addition of vermiculite could improve the agronomics of crop and plant systems in the long term. In Fig. 5, we plot the kikuyu shoot DMY for only the last four cuts from the Sodosol pots. Although not statistically significant $(P=0.1)$, there was a strong correlation $\left(r^{2}=0.87\right)$ between DMY and vermiculite addition level for these final cuts. This suggests an effect where vermiculite-sorbed $\mathrm{NH}_{4}-\mathrm{N}$ is gradually nitrified and made available to plants as other sources of $\mathrm{N}$ become increasingly scarce, through leaching, plant uptake and gaseous loss.

This agronomic effect towards the end of the trial may relate to $\mathrm{N}$ deficiency in the Sodosol pots. Determining N deficiency is not straightforward because the resident soil $\mathrm{N}$, as well as the applied manure and urea $\mathrm{N}$, contributes to microbial activity. $\mathrm{N}$ uptake by the pasture exceeded manure and urea $\mathrm{N}$ additions by a factor of $>2$ for the Ferrosol treatments over the trial. The plants were clearly tapping into the soil $\mathrm{N}$ content, which was

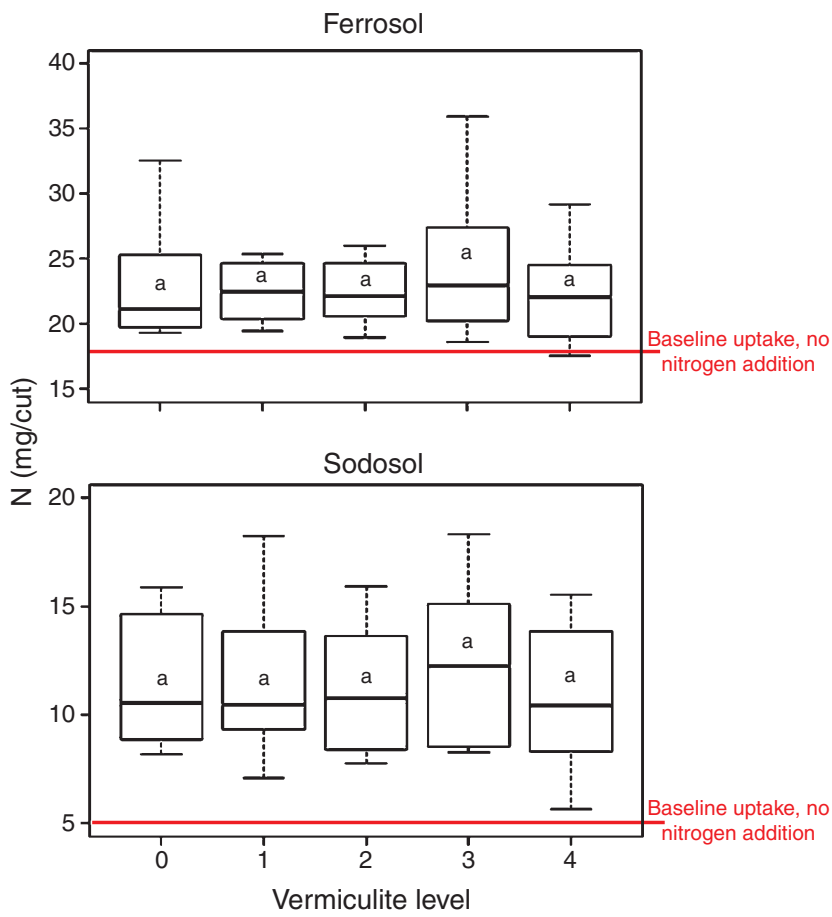

Fig. 4. Box and whisker plots for $\mathrm{N}$ uptake in harvested kikuyu shoots. Common letters indicate that values are not significantly different $(P=0.05)$. Refer to Table 1 for vermiculite addition levels.

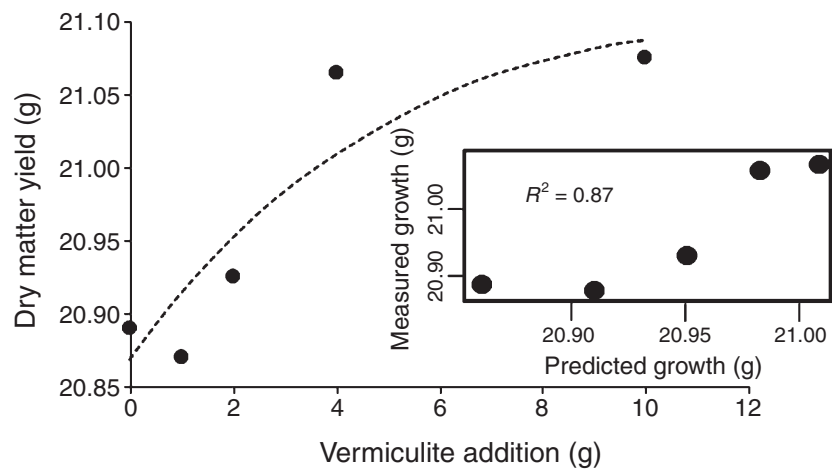

Fig. 5. Regression between mean dry matter yields from the harvested kikuyu shoots from Sodosol and the level of vermiculite addition for the final three cuts in the trial. Inset graphic shows correlation between measured growth and predicted growth. Refer to Table 1 for vermiculite addition levels.

34 times higher than the applied manure and urea N. The Sodosol plants also took-up a high proportion of the applied manure and urea $\mathrm{N}(\sim 80 \%$ across all vermiculite levels), and the soil $\mathrm{N}$ contribution in these treatments was much lower than for the Ferrosol treatments (soil N 11 times higher than the applied manure and urea N). By the end of the trial, it is likely that the pots were deficient in $\mathrm{N}$, and the increase in yield with vermiculite treatment (Sodosol soil) may have been a response to deferred nutrient release related to desorption from the vermiculite into soil solution. Glasshouse trials are also less likely to result in $\mathrm{N}$ leaching as watering is controlled to limit 
losses, thus delaying nutrient deficiency that can be seen in field-scale environments. In the subsequent field trial, clays increased DMY by $20 \%$. Here, we suggest the following two potential agronomic benefits that clays might offer over chemical inhibitors: (1) lower environmental and contaminant risks; and (2) a supply-on-demand pattern of $\mathrm{N}$ delivery to plants, compared with inhibitors where $\mathrm{N}$ release is directly related to soil and environmental conditions. Thus, our clay-based technology clearly has merit as an effective GHG mitigation strategy, with potential associated agronomic benefits.

\section{Further considerations}

Critical examination of the logistics of developing a clay-based GHG mitigation technology is needed. Data on expected embodied emissions associated with obtaining the clays are required to determine whether there is a net $\mathrm{GHG}$ reduction benefit achievable by going down this path. Our team is currently performing a life cycle analysis on the results reported here, with the outcomes planned for publication in a follow-up manuscript.

\section{Conclusions}

Vermiculite was shown to be highly effective in supressing $\mathrm{N}_{2} \mathrm{O}$ emissions from a variety of manures and urea incorporated into a clayey and sandy soil supporting a model plant (kikuyu). At its highest addition rate (1:1 manure dry weight), the high-CEC clay brought about an average $\mathrm{N}_{2} \mathrm{O}$ emission decrease of $70 \%$ across five $\mathrm{N}$ sources (four manures and urea), two soil types and two $\mathrm{N}$ loading rates. Importantly, the addition of vermiculite did not adversely affect growth rates of the model kikuyu plant. Indeed, towards the end of the trial, when the plants were showing signs of $\mathrm{N}$ depletion, we observed encouraging evidence that the vermiculite additions were causing improved agronomic yields. Further work, including field-testing, life cycle analysis and cost-benefit analysis, is needed to develop the approach into a workable technology that can be rolled-out at field scale.

\section{Acknowledgements}

This research was funded by the Australian Government, University of Queensland, Meat and Livestock Australia, Australian Pork Limited, Rural Industries Research and Development Corporation and Australian Egg Corporation Limited as part of the National Agricultural Manure Management Program. We thank those farmers who permitted access to their sites. Thanks go to Warwick Nash, Ray King, Ian Kruger and Janine Price for their constructive comments on the manuscript. We are appreciative of the technical inputs of Grant Brown, John McAlpine, Gregor McAuley, Tahlia Duncan and Maren Westermann.

\section{References}

Amon B, Kryvoruchko V, Amon T, Zechmeister-Boltenstern S (2006) Methane, nitrous oxide and ammonia emissions during storage and after application of dairy cattle slurry and influence of slurry treatment. Agriculture, Ecosystems \& Environment 112, 153-162. doi:10.1016/ j.agee.2005.08.030

Beare MH, Gregorich EG, St-Georges P (2009) Compaction effects on $\mathrm{CO}_{2}$ and $\mathrm{N}_{2} \mathrm{O}$ production during drying and rewetting of soil. Soil Biology \& Biochemistry 41, 611-621. doi:10.1016/j. soilbio.2008.12.024
Bouwman AF (1996) Direct emission of nitrous oxide from agricultural soils. Nutrient Cycling in Agroecosystems 46, 53-70. doi:10.1007/ BF00210224

Buckee GK (1994) Determination of total nitrogen in barley, malt and beer by Kjeldahl procedures and the Dumas combustion method: collaborative trial. Journal of the Institute of Brewing 100, 57-64.

Cederberg C, Hedenus F, Wirsenius S, Sonesson U (2013) Trends in greenhouse gas emissions from consumption and production of animal food products: implications for long-term climate targets. Animal 7, 330-340. doi:10.1017/S1751731112001498

Chadwick DR, Pain BF, Brookman SKE (2000) Nitrous oxide and methane emissions following application of animal manures to grassland. Journal of Environmental Quality 29, 277-287. doi:10.2134/jeq2000.0047242 5002900010035x

Danaher M, Jordan K (2013) Identification of existing and emerging chemical residue contamination concerns in milk. Irish Journal of Agricultural and Food Research 52, 173-183.

Dell CJ, Kleinman PJA, Schmidt JP, Beegle DB (2012) Low-disturbance manure incorporation effects on ammonia and nitrate loss. Journal of Environmental Quality 41, 928-937. doi:10.2134/jeq2011.0327

El-Mashad HM, Zhang R (2010) Biogas production from co-digestion of dairy manure and food waste. Bioresource Technology 101, 4021-4028. doi:10.1016/j.biortech.2010.01.027

GenStat (2013) 'GenStat for Windows, release 15.3.' (VSN International: Oxford, UK)

Ginting D, Kessavalou A, Eghball B, Doran JW (2003) Greenhouse gas emissions and soil indicators four years after manure and compost applications. Journal of Environmental Quality 32, 23-32. doi:10.2134/ jeq2003.2300

Gregorich EG, McLaughlin NB, Lapen DR, Ma BL, Rochette P (2014) Soil compaction, both an environmental and agronomic culprit: increased nitrous oxide emissions and reduced plant nitrogen uptake. Soil Science Society of America Journal 78, 1913-1923. doi:10.2136/sssaj 2014.03.0117

Inoue K, Sakamoto T, Min JZ, Todoroki K, Toyo'oka T (2014) Determination of dicyandiamide in infant formula by stable isotope dilution hydrophilic interaction liquid chromatography with tandem mass spectrometry. Food Chemistry 156, 390-393. doi:10.1016/j.food chem.2014.01.124

Koneswaran G, Nierenberg D (2008) Global farm animal production and global warming: impacting and mitigating climate change. Environmental Health Perspectives 116, 578-582. doi:10.1289/ehp.11034

Krogmeier MJ, McCarty GW, Bremner JM (1989) Potential phytotoxicity associated with the use of soil urease inhibitors. Proceedings of the National Academy of Sciences, USA 86, 1110-1112. doi:10.1073/ pnas.86.4.1110

Lessard R, Rochette P, Gregorich EG, Pattey E, Desjardins RL (1996) Nitrous oxide fluxes from manure-amended soil under maize. Journal of Environmental Quality 25, 1371-1377. doi:10.2134/jeq1996.00472 $425002500060029 \mathrm{x}$

Lin X, Hasi W-L-J, Lou X-T, Han S-Q-G-W, Lin D-Y, Lu Z-W (2015) Direct and quantitative detection of dicyandiamide (DCD) in milk using surface-enhanced Raman spectroscopy. Analytical Methods 7, 3869-3875. doi:10.1039/C5AY00313J

McMichael AJ, Powles JW, Butler CD, Uauy R (2007) Food, livestock production, energy, climate change, and health. Lancet 370, 1253-1263. doi:10.1016/S0140-6736(07)61256-2

McTaggart IP, Clayton H, Parker J, Swan L, Smith KA (1997) Nitrous oxide emissions from grassland and spring barley, following $\mathrm{N}$ fertiliser application with and without nitrification inhibitors. Biology and Fertility of Soils 25, 261-268. doi:10.1007/s003740050312

Mosier A, Kroeze C, Nevison C, Oenema O, Seitzinger S, van Cleemput O (1998) Closing the global $\mathrm{N}_{2} \mathrm{O}$ budget: nitrous oxide emissions through 
the agricultural nitrogen cycle. Nutrient Cycling in Agroecosystems 52, 225-248. doi:10.1023/A:1009740530221

Mumpton FA, Fishman PH (1977) The application of natural zeolites in animal science and aquaculture. Journal of Animal Science 45, 1188-1203.

Natvig EE, Ingham SC, Ingham BH, Cooperband LR, Roper TR (2002) Salmonella enterica serovar Typhimurium and Escherichia coli contamination of root and leaf vegetables grown in soils with incorporated bovine manure. Applied and Environmental Microbiology 68, 2737-2744. doi:10.1128/AEM.68.6.2737-2744.2002

Pal P, McMillan AMS, Saggar S (2015) 'Routes of dicyandiamide uptake in pasture plants: a preliminary glasshouse study.' Occasional report no. 28. (Eds LD Currie, LL Burkitt) pp. 1-9. (Fertilizer and Lime Research Centre, Massey University: Palmerston North, New Zealand) Available at http://flrc.massey.ac.nz/publications.html [Verified 30 November 2015]

Pratt C, Redding M, Hill J, Jensen PD (2015a) Does manure management affect the latent greenhouse gas emitting potential of livestock manures? Waste Management 46, 568-576.

Pratt C, Redding MR, Hill J (2015b) Application of sorbers to mitigate greenhouse gas emissions from land-applied pig litter. Animal Production Science, in press.

Pratt C, Redding MR, Hill J, Brown G, Westermann M (2016) Clays can decrease gaseous nutrient losses from soil-applied livestock manures. Journal of Environmental Quality, in press.

Ravishankara AR, Daniel JS, Portmann RW (2009) Nitrous oxide $\left(\mathrm{N}_{2} \mathrm{O}\right)$ : the dominant ozone-depleting substance emitted in the 21 st century. Science 326, 123-125. doi:10.1126/science.1176985

Redding MR (2011) Bentonites and layered double hydroxides can decrease nutrient losses from spent poultry litter. Applied Clay Science 52, 20-26. doi:10.1016/j.clay.2011.01.016
Redding MR, Shorten PR, Lewis R, Pratt C, Paungfoo-Lonhienne C, Hill J (2016) Soil N availability, rather than $\mathrm{N}$ deposition, controls indirect $\mathrm{N}_{2} \mathrm{O}$ emission. Soil Biology and Biochemistry, in press.

Rochette P, Angers DA, Chantigny MH, Gagnon B, Bertrand N (2008) $\mathrm{N}_{2} \mathrm{O}$ fluxes in soils of contrasting textures fertilized with liquid and solid dairy cattle manures. Canadian Journal of Soil Science 88, 175-187. doi:10.4141/CJSS06016

Saggar S, Singh J, Giltrap DL, Zaman M, Luo J, Rollo M, Kim DG, Rys G, der Weerden TJv (2013) Quantification of reductions in ammonia emissions from fertiliser urea and animal urine in grazed pastures with urease inhibitors for agriculture inventory: New Zealand as a case study. The Science of the Total Environment 465, 136-146. doi:10.1016/ j.scitotenv.2012.07.088

Shcherbak I, Millar N, Robertson GP (2014) Global metaanalysis of the nonlinear response of soil nitrous oxide $\left(\mathrm{N}_{2} \mathrm{O}\right)$ emissions to fertilizer nitrogen. Proceedings of the National Academy of Sciences, USA 111, 9199-9204. doi:10.1073/pnas.1322434111

Sherlock RR, Sommer SG, Khan RZ, Wood CW, Guertal EA, Freney JR, Dawson CO, Cameron KC (2002) Ammonia, methane, and nitrous oxide emission from pig slurry applied to a pasture in New Zealand. Journal of Environmental Quality 31, 1491-1501. doi:10.2134/jeq 2002.1491

Snyder CS, Davidson EA, Smith P, Venterea RT (2014) Agriculture: sustainable crop and animal production to help mitigate nitrous oxide emissions. Current Opinion in Environmental Sustainability 9-10, 46-54. doi:10.1016/j.cosust.2014.07.005

Sumner ME, Miller WP (1996) 'Cation exchange capacity and exchange coefficients.' (Soil Science Society of America and American Society of Agronomy: Madison, WI)

Zaman M, Nguyen ML, Matheson F, Blennerhassett JD, Quin BF (2007) Can soil amendments (zeolite or lime) shift the balance between nitrous oxide and dinitrogen emissions from pasture and wetland soils receiving urine or urea-N? Soil Research 45, 543-553. doi:10.1071/SR07034 